\title{
Gonadotropin-releasing hormone receptor gene mutation: a new cause of hereditary hypogonadism and another mutated G-protein-coupled receptor
}

\author{
Jérôme Bertherat \\ Clinique des Maladies Endocriniennes et Métaboliques, Hôpital Cochin, 27 rue du Faubourg-St-Jacques, 75014 Paris, France
}

The list of activating and inactivating mutations of the G-protein-coupled receptors with seven transmembrane domains involved in endocrine diseases is increasing rapidly. Two reports $(1,2)$ have recently added inactivating mutations of the gonadotropin-releasing hormone receptor (GnRHR) to the list. Hereditary hypogonadotropic hypogonadism $(\mathrm{HH})$ is genetically heterogeneous, and so far only some forms of X-linked recessive inheritance have been explained. The wellknown X-linked form of $\mathrm{HH}$ associated with anosmia is Kallmann's syndrome due to mutations of the KALIG-1 gene located to chromosome Xp22.3 (3, 4). Mutation of the chromosome Xp21-located gene of the transcription factor DAX (DSS-AHC critical region of the X chromosome, gene 1) causes congenital adrenal hypoplasia and HH (5). Nevertheless, these two genetic defects do not explain all the cases of familial $\mathrm{HH}$ and this disease is not always linked to the $\mathrm{X}$ chromosome. Therefore, it was tempting to search for other candidates. Since gonadotropin-releasing hormone (GnRH) plays a major role in the central control of the gonadotropic axis, it was a possible candidate. Indeed mutation of the $\mathrm{GnRH}$ gene was first reported in the hypogonadal mouse more than 10 years ago (6), but a similar mutation has never been reported in humans (7).

GnRHR is a member of the family of G-proteincoupled receptors with seven transmembrane domains. Binding of GnRH to its receptor stimulates the activity of phospholipase $\mathrm{C}$ and intracellular calcium trough $\mathrm{Gq} / \mathrm{G} 11$ proteins (see refs $(1,2)$ for reviews). The human GnRHR gene is located on chromosome 4 and comprises three exons. As the response to exogenous $\mathrm{GnRH}$ is quite variable among patients with $\mathrm{HH}$, it was tempting to postulate a GnRHR defect in some patients. Layman et al. (2) have screened 46 unrelated patients with $\mathrm{HH}$ (32 males and 14 females) without anosmia and have identified two GnRHR gene mutations in one patient. As in the family presenting with $\mathrm{HH}$ reported by De Roux et al. (1), the affected siblings are compound heterozygotes for GnRHR gene mutation. In both families, females as well as males are affected, in keeping with the chromosomal localization of the GnRH gene. This is the first genetic explanation for an autosomal form of familial $\mathrm{HH}$ in humans. Three missense mutations of the GnRHR gene are reported in these two families. One mutation led to a Q106R substitution in the first extracellular loop of the receptor, leading to a dramatic reduction in $\mathrm{GnRH}$ binding (1). A second mutation is present in both families and causes a R262Q substitution in the third intracellular loop, leading to a decrease in inositol phosphate production in response to GnRH stimulation $(1,2)$. The last mutation is responsible for a Y284C substitution in the sixth transmembrane region, also altering the signal transduction of the mutant GnRHR (2).

Interestingly, basal plasma levels of follicle-stimulating hormone (FSH) or luteinizing hormone (LH) are not always low and are even reported in the normal range in some affected siblings presenting with $\mathrm{HH}$ from these two families. The FSH and LH response to exogenous GnRH is not decreased, suggesting that the receptor defect is only partial and could be masked by a supraphysiological dose of GnRH used for the stimulation tests. Furthermore, LH pulsatility studied in one of these patients showed a dramatic reduction in pulse amplitude despite a normal pulse frequency (1). This last observation might be in keeping with a partial defect of the GnRH mutant receptors. It will therefore be difficult for the clinician to select patients for a GnRHR gene study only on the basis of the gonadotropin basal or stimulated plasma levels.

The determination of the prevalence of GnRHR mutations in patients with $\mathrm{HH}$ will be important. According to the first screening performed by Layman et al. (2), GnRHR mutation would occur in $2.2 \%$ of patients with idiopathic $\mathrm{HH}$, but this rate will increase to $7.1 \%$ when only families with an affected female are considered (2).

\section{References}

1 De Roux N, Young J, Misrahi M, Genet R, Chanson P, Schaison G \& Milgrom E. A family with hypogonadotropic hypogonadism and mutations in the gonadotropin-releasing hormone receptor. New England Journal of Medicine 1997337 1597-1602.

2 Layman LC, Cohen DP, Jin M, Xie J, Li Z, Reindollar RH et al. Mutations in gonadotropin-releasing hormone receptor gene cause hypogonadotropic hypogonadism. Nature Genetics 199818 14-15.

3 Meitinger T, Heye B, Petit C, Leilliers J, Golla A, Moraine C et al. Definitive localization of X-linked Kallman syndrome (hypogonadism and anosmia) to Xp22.3: close linkage to the hypervariable repeat sequence CRI-S232. American Journal of Human Genetics $199047664-669$.

4 Bick D, Franco B, Sherins RJ. Heye B, Pike L, Crawford J et al. Intragenic deletion of the KALIG-1 gene in Kallmann's syndrome. New England Journal of Medicine 1992326 1752-1755. 
5 Zanaria E, Muscatelli F, Bardoni B, Strom TM, Guioli S, Guo Wet al. An unusual member of the nuclear hormone receptor superfamily responsible for X-linked adrenal hypoplasia congenita. Nature $1994372635-641$.

6 Masson AJ, Hayflick JS, Zoeller RT, Young WS III, Phillips HS, Nikolils $\mathrm{K} \&$ Seeburg PH. A deletion truncating the gonadotropin-releasing hormone gene is responsible for hypogonadism in the hpg mouse. Science 1986234 1366-1371.

7 Weiss J, Crowley WF \& Jameson JL. Normal structure of the gonadotropin-releasing hormone $(\mathrm{GnRH})$ gene in patients with GnRH deficiency and idiopathic hypogonadotropic hypogonadism. Journal of Clinical Endocrinology and Metabolism 198969 299-303. 